\title{
Woordeboek en gebruik: 'n bose kringloop
}

\author{
A.F. Prinsloo, Taalburo, Suid-Afikaanse Uitsaaikorporasie (SAUK)
}

\begin{abstract}
Dictionary and Usage: A Vicious Circle. This study examines the statement that the practice of compiling Afrikaans explanatory and translating dictionaries by excerpting from published material has created a vicious circle that results in the exclusion from dictionaries of lexical items regarded as standard language by educated mother-tongue speakers of Afrikaans. The reason for this is that language in excerpted publications (books, magazines, newspapers) is usually sub-edited to a greater or lesser degree by language practitioners who in tum follow the prescriptions of dictionaries. The result is a vicious circle that is entrenched further by lexicographical standardizing techniques such as exclusion or negative labelling. The three main issues discussed in the study are (a) prescriptions to the prescribers (lexicographers); (b) the treatment of sixteen lexical items in dictionaries and language manuals; (c) results of an empirical investigation of these sixteen cases among five groups of educated mother-tongue speakers (102 respondents in all). The conclusion is that Afrikaans explanatory and translating dictionaries do not yet reflect the usage of these cases (and by implication many others).
\end{abstract}

Keywords: USUAL, ACCEPTABLE, UNUSUAL, UNACCEPTABLE, RESPONSE, EXCERPTION, CIRCLE, LABELLING, RESPONDENTS, QUESTIONNAIRE, DIGLOSSIA, STANDARD LANGUAGE, LEXICOGRAPHY

Opsomming: Dié studie ondersoek die stelling dat Afrikaanse verklarende en vertalende woordeboeke as gevolg van die ekserpering van bykans uitsluitlik gepubliseerde stof 'n bose kringloop tot stand bring waardeur leksikale items wat deur opgevoede moedertaalsprekers van Afrikaans as standaardtaal beskou word, uit die woordeboek geweer word. Die taalgebruik in die geëkserpeerde publikasies (boeke, tydskrifte, koerante) word naamlik altyd in mindere of meerdere mate talversorg deur talpraktisyns wat op hulle beurt weer die voorskrifte van die woordeboek volg. Hierdeur kom 'n bose kringloop tot stand wat in die woordeboek verder verskans word deur leksikografiese normeringstegnieke soos weglating en/of afwysende etikettering. Veral drie sake word in dié studie bespreek, naamlik (a) die voorskrifte aan die voorskrywers (die leksikograwe), (b) die behandeling van sestien leksikale items in woordeboeke en taalhandleidings, en (c) die resultate van 'n empiriese ondersoek van dié sestien gevalle onder vyf groepe opgevoede moedertaalsprekers ('n totaal van 102 respondente). Daar word tot die gevolgtrekking gekom dat Afrikaanse verkJarende en vertalende woordeboeke tot dusver nie die gebruikJikheid van dié gevalle (en by implikasie ook van talle ander) weerspieël nie.

Sleutelwoorde: GEBRUIKLIK, AANVAARBAAR, ONGEBRUIKLIK, ONAANVAARBAAR, RESPONS, EKSERPERING, KRINGLOOP, ETIKETTERING, RESPONDENTE, VRAELYS, DIGLOSSIE, STANDAARDTAAL, LEKSIKOGRAFIE 
Enige waarnemer van gesproke Afrikaans kom te staan voor die verskynsel dat die moedertaalspreker, selfs (of juis) die "opgevoede" moedertaalspreker, sekere woorde of uitdrukkings of kollokasies gebruik wat nie as Standaardafrikaans beskou word nie, al sou die spreker andersins as 'n standaardspreker getipeer kan word.

Die meeste van hierdie taalgebruiksitems, hoe gebruiklik ook al, word nie in woordeboeke aangetref nie. Die oorsaak vir hierdie toedrag van sake vorm die vertrekpunte van hierdie studie, naamlik (a) dat die beginsel van gebruik as norm vir die opname van leksikale items in woordeboeke irrelevant word wanneer die geringste moontlikheid bestaan dat dié items Engelse invloed vertoon; (b) dat Afrikaanse verklarende en vertalende woordeboeke as gevolg van die ekserpering van bykans uitsluitlik gepubliseerde stof nie genoegsaam rekenskap gee van die Standaardafrikaanse spreektaal nie; en (c) dat aangesien die geëkserpeerde publikasies (boeke, tydskrifte, koerante) altyd in mindere of meerdere mate taalversorg word deur taalpraktisyns wat op hulle beurt die norme van die woordeboek toepas, 'n bose kringloop tot stand kom. As die woordeboek 'n leksikale item nie opneem nie, of afwysend etiketteer (byvoorbeeld as "ongewenste Anglisisme"), gaan die taalversorger dié item ten alle koste uit publikasies weer - en gaan die ekserpeerder van die publikasies nie die item aanteken nie omdat dit nêrens verskyn nie.

Met verwysing na die behandeling van die "steurendste Anglisismes" in hulle taalhandleiding, sê Combrink en Spies (1986: 14): "... Ook hier geld die goue reël vir alle skrywers: hou 'n goeie woordeboek byderhand en slaan na, selfs wanneer jy nie twyfel nie." Die gewone taalgebruiker besef gewoonlik nie dat woordeboeke nie alle leksikale items van 'n taal kan opneem nie, en beskou dus die weglating van ' $n$ item as aanduiding dat dit nie bestaan nie. Dat dit wel kan bestaan, maar deur die leksikograaf as Anglisisties beskou en dus weggelaat word, is waarskynlik nie deel van die gewone taalgebruiker se kennis van woordeboeke nie.

Dat daar wel 'n Anglisismevrees by Afrikaanssprekers bestaan, blyk duidelik uit vraag 11 in die vraelys (Tabel 6) waar ' $n$ beduidende persentasie van die proefpersone die Afrikaanse werkwoord oorkóm (met die betekenis van "te bowe kom") as onaanvaarbaar bestempel - dit word gesien as 'n direkte vertaling van die Engelse werkwoord "overcome". Dit is betekenisvol dat die vraelys ingevul is sonder dat woordeboeke geraadpleeg kon word - waarin dié item as gewone Standaardafrikaans erken word. Hoewel oorkom met dié betekenis uit Nederlands na Afrikaans gekom het, is Van der Merwe en Ponelis (1982: 16) se opmerking oor Anglisismes hier van toepassing: "... daar moet onthou word dat Engels ook baie verrykend op Afrikaans ingewerk het: gesonde, ewewigtige oordeel is nodig want 'n heksejag op Engelse beinvloeding gaan ons beslis nie ver bring nie." 
Om bogemelde vertrekpunte te toets, is daar enersyds gekyk na die voorskrifte vir leksikograwe oor die stof waarop die woordeboek gebaseer behoort te word, en andersyds die menings van 102 respondente ingewin oor leksikale items waarvan die gebruik deur woordeboeke en taalhandleidings grotendeels afgekeur word. Inligting oor die vraelyste, die respondente en die resultate word in die tweede en derde afdeling van hierdie studie verstrek.

\section{A. Voorskrifte aan die voorskryzuers}

Daar bestaan vandag eenstemmigheid dat die gesag van die woordeboek deur die gewone taalgebruiker as volstrek aanvaar word. Dit word nie verder beredeneer nie: Sedert Odendal (1978) daaroor begin skryf het, het die gedagterigting sodanig verander dat daar vandag aanvaar word dat woordeboeke ook ' $n$ preskriptiewe funksie het (dit moontlik ook nog altyd gehad het).

Die aanvaarding van dié toedrag van sake word ook duidelik daarin weerspieël dat Gouws (1989: 13) in sy aanvangsparagraaf die volgende sonder verdere argumentasie as die siening van die gewone taalgebruiker kan stel: "'n Publikasie met woordeboek in sy titel verkondig die absolute waarheid ... Woordeboeke ... word vir die volle spektrum van taalkundige probleme geraadpleeg. Die woordeboek word dan werklik vir so 'n gebruiker ' $n$ bron van taalkundige inligting en die gesag van die woordeboek staan bo alle verdenking."

Om tot 'n definisie van "gewone taalgebruiker" en van "opgevoede moedertaalspreker" te kom, kan probleme oplewer. Of outeurs, redakteurs, taalversorgers e.d.m. as gewone taalgebruikers of as opgevoede moedertaalsprekers beskou moet word, is nie werklik hier ter sprake nie: almal aanvaar egter die gesag van die woordeboek - 'n stelling wat getoets kan word aan enige taalburo wat erns maak met Afrikaans.

As ' $n$ woordeboek dus 'n leksikale item nie opneem nie, ervaar die gebruiker daarvan dit as 'n afkeuring van die betrokke item. Hoewel dit hoogstens ' $n$ persepsie by die gebruiker kan wees, is dit vir hom die taalwerklikheid: As 'n woord nie in die woordeboek verskyn nie, bestaan dit nie en mag dit dus ook nie gebruik word nie. In talle gevalle ken die gebuiker die betekenis van 'n woord - hy wil slegs weet of die woordeboeke sanksie daaraan verleen. (Slegs in enkele gevalle word die weglating beskou as ' $n$ teken dat die woordeboek hom nie teen 'n sekere item uitlaat nie, en dat dit dus Standaardafrikaans is: 'n argumentum e silentio.)

Op dieselfde gesaghebbende wyse beïnvloed die woordeboek die gebruiker deur middel van etikettering. Die vrees vir Anglisismes is by die Afrikaansspreker so ingeburger dat etikette soos (in stygende orde van ongewenstheid) onder Engelse invloed, waarskynlik na die Engels, Anglisisme, ongewenste Anglisisme die betrokke leksikale item vir gebruik ongeskik verklaar - asof dit weggelaat is. Volgens Gouws (1988: 9) word "etikette ... so gekies dat dit een of ander afwyking van die standaardtaal moet merk, d.w.s. 'n bepaalde beperking op die gebruik van die lemma". Sy bespreking van stilistiese etikette (1988: 32 
e.v. en 1989: 204 e.v.) dek ongelukkig nie dié wat met Anglisismes verband hou nie.

Dit is duidelik dat die opname van sogenaamde Anglisismes 'n dilemma in die Afrikaanse leksikografie skep. Enersyds is daar die eis aan die leksikograaf dat gebruik as grondslag vir opname moet dien; andersyds rus daar die tradisionele verpligting op hom dat Engelse invloed uit Afrikaans geweer moet word. Die probleem is dat die taalkontaksituasie in Suid-Afrika daartoe lei dat Engels toenemend die taalgebruik van Afrikaanse moedertaalsprekers beïn. vloed. Dit is duidelik waameembaar in gesproke Afrikaans - in geskrewe Afrikaans, soos reeds gesê is, word die Engelse invloed deur middel van die woordeboek en taalhandleiding se voorskrifte beperk.

Die vraag wat hieruit ontstaan, is of die Afrikaanse taal op pad is na ' $n$ toestand van 'diglossie' wat Zgusta (1971: 226-227) as volg bespreek: "If we are dealing with a language that has a very strong diglossia, i.e. if the written texts differ vastly from the spoken ones, we have two possible courses of action. Either we can decide that we shall compile a dictionary of the literary standard national language, ... or we decide that we shall take into consideration the spoken forms, too; in the latter case, it is necessary to explore the spoken variety as a language of its own, i.e. excerpt the oral texts, etc."

In 'n voetnoot meld hy (Zgusta 1971: 227) egter: "If there is such a situation in a language, the spoken form is usually on the verge of becoming the medium of written communications also."

Gouws (1989: 30) wys daarop dat die benadering van Gove in Webster ${ }^{3}$ tot die weergawe van taal in ' $n$ woordeboek daartoe gelei het dat "al hoe meer aandag gegee is aan die woordeboek as neerslagplek van werklike taalgebruik [my kursivering - AFP]. 'n Woordeboek moet gebruik weergee".

Hy verwys na die Collins COBUILD-woordeboek (1987) wat saamgestel is "deur ' $n$ keuse te doen uit ' $n$ verteenwoordigende versameling gesproke en geskrewe Engelse tekste ..."

Dit is op hierdie besondere punt waar die onderhawige studie aansluit: Nieteenstaande die voorskrifte aan die voorskrywers (by wyse van spreke) vind gesproke Afrikaanse taalgebruik in baie gevalle nie neerslag in Afrikaanse verklarende en vertalende woordeboeke nie. Dié stelling is ondersoek deur middel van ' $n$ vraelys waarin die menings van 102 respondente oor 16 leksikale items verkry is. Die keuse van die items in die vraelys en groepe respondente, die behandeling van die items in woordeboeke en taalhandleidings, die resultate van die vraelysopname en die geldigheid van die vraelys word vervolgens bespreek. 


\section{B. Die empiriese studie}

Die keuse van die items:

Die items bestaan hoofsaaklik uit "taalfoute" wat oor 'n tydperk van sewe jaar (1984-1990) deur die SAUK se Komitee vir Taaladvies aangestip is. Die Komitee het meer as drie dekades gelede ontstaan as ' $n$ komitee van die Suid-Afrikaanse Akademie vir Wetenskap en Kuns om 'n wakende ogie oor die Afrikaanse taalgebruik van die radio te hou. Die Komitee is intussen uitgebrei, maar behandel nog steeds elke twee maande taalkwessies en "taalfoute" onder die leiding van vier senior Afrikaanse taalkundiges. Dit vervul 'n onontbeerlike funksie omdat die sake op die agenda in die meeste gevalle nuut is, d.w.s. (nog) nie in woordeboeke en taalhandleidings bespreek word of in die AWS verskyn nie.

Oor die tydperk van sewe jaar het sowat 240 items herhaaldelik voorgekom: daaruit is ongeveer 150 gekies en aan twee proefgroepe voorgelê (groep A en C - tabel 1 en 3 onderskeidelik) om hulle mening oor die gebruiklikheid of ongebruiklikheid, aanvaarbaarheid of onaanvaarbaarheid van die taalgebruiksitems uit te spreek. Op grond van dié resultate is die sestien items gekies wat deur die groepe as die gebruiklikste beskou is en ook 'n hoë mate van aanvaarding geniet het.

Daar moet onmiddellik ook vermeld word dat sekere items deur meer as 90 persent van die proefpersone as gebruiklik beskou is, maar vir ongeveer 80 persent van hulle onaanvaarbaar was, bv. huidiglik, hy groei 'n baard e.a.

Die sestien items wat aan die vyf groepe respondente voorgelê is, is:

1. Inflasie het gekom om te bly

2. 'n Klag/aanklag teen iemand $l \hat{e}$

3. Tom P. sal die rekord breek

4. Die tellings is in die twintigs

5. Doen aansoek vir die pos

6. Sy het ' $n$ sê in die saak

7. Dit dien geen doel nie

8. Soldate op die grens

9. Buite orde reël

10. Die rivier is in vloed

11. Probleme aorkóm ("te bowe kom")

12. Te oordeel aan

13. Hy doen by Heilbron aan

14. 'n Belofte maak

15. Vonnisse gelyktydig uitdien

16. Melkskommel (bruismelk) 
Die keuse van die proefgroepe:

Die proefgroepe het bestaan uit persone wat Afrikaans minstens tot op derdejaarsvlak aan 'n universiteit of kollege bestudeer het, of andersins indiensopleiding oor ' $n$ tydperk van jare ondergaan het, byvoorbeeld in die skryf van Afrikaanse tekste by radio en televisie.

Met hierdie keuse is daar probeer om juis die menings van ' $n$ aantal "bogemiddeld opgevoede" Afrikaanse moedertaalsprekers te verkry. Die feit dat daar persone was wat by sommige items moes vra wat die betrokke taalfout is, dui daarop dat "gewone moedertaalsprekers" (sê byvoorbeeld Afrikaanssprekers wat na matriek geen verdere onderrig in die taal ontvang het nie) se menings na alle waarskynlikheid nog nader aan die boonste perke van gebruiklikheid en aanvaarbaarheid sou lê.

Die sestien items in woordeboeke en taalhandleidings:

Die afkortings van die titels van woordeboeke en taalhandleidings wat in hierdie bespreking gebruik word, is: GW - Groot Woordeboek, RD - Reader's Digest Afrikaans-Engelse Woordeboek, HAT - Verklarende Handwoordeboek van die Afrikaans Taal, NW - Nasionale Woordeboek en WAT - Woordeboek van die Afrikaanse Taal; SARA - Sakboek van regte Afrikaans, KW - Die korrekte woord, JW - Die juiste woord, VW - Voorsetselwoordeboek en KG - Die Kennis gids tot moderne Afrikaans. As 'n publikasie nie by 'n leksikale item vermeld word nie, beteken dit dat dit nie in die betrokke werk(e) opgeneem is nie. (Die Verklarende Afrikaanse Woordeboek is buite rekening gelaat om verskeie redes: een daarvan is dat items uit vreemde tale (bv. courtoisie, cui bonum, faillissement en talle meer) en Afrikaanse woorde wat deur die meeste sprekers as onfatsoenlik of plat beskou word (bv. kak) sonder enige etiket opgeneem is, waarmee te kenne gegee word dat dit leksikale items van Standaardafrikaans is.)

1. ... gekom om te bly

Die GW se inskrywing by "come to stay" is dit het ' $n$ blywende plek gekry; RD: dit sal bly; die HAT, NW en WAT bevat geen inskrywing nie.

2. 'nklag/aanklag lê

GW: 'n aanklag indien

RD: indien/inbring

HAT: indien

WAT: 'n klag indien - maar met die interessante verskynsel dat die tweede sitaat dit weerspreek: "Ek is baie lus om 'n klag van kin- 
derverwaarlosing teen julle twee te lê (H.S. v. Blerk: Son, 1965, 37)."

KW: $\quad$ "Naas ' $n$ klag inbring teen iemand het ' $n$ klag lê onder Engelse invloed gevestig geraak" (bl.104).

KG: $\quad$ "n Aanklag word ingedien of ingebring, nie 'gelè' nie" (bl. 13).

3. ...'n rekord breek

GW: $\quad$ slaan, verbeter

RD: breek (verbeter, slaan). In 'n kantlynaantekening verskyn die volgende: "Previously frowned-upon expressions with rekord that are now firmly established [my kursivering - AFP] as a part of the vocabulary of Afrikaans are: ' $n$ rekord breek (break a record) ..." (bl. 435).

HAT en NW: slaan, verbeter

SARA: '"n Rekord breek is stewig ingeburger en word ook in Van Dale erken. Van Dale gee ook slaan, maar dis moeilik te begryp hoe enige van die gewone betekenisse van die woord in Afrikaans hier van toepassing kan wees" (bl. 135).

KW: $\quad$ "n Rekord word geslaan en nie gebreek nie" (bl. 164).

Nieteenstaande die RD en SARA se uitsprake, blyk uit Tabel 6 dat sowat 90 persent van die respondente dié item as gebruiklik beskou het, maar dat meer as 46 persent dit nog steeds onaanvaarbaar vind.

4. ... in die twintigs

GW, RD, HAT: twintigerjare, in die twintig

NW: twintigerjare

WAT: dertiger jare [sic]. Dit word egter as 'n germanisme aangedui.

SARA: 'Toe hy in sy 'twintigs' ... was. Met goeie Afrikaans soos oor die veertig ... in sy veertigerjare het ons hierdie esserige Engelse vorm nie nodig nie" (bl. 34).

KW: "Sy is in haar twintigs ... is anglisisties [sic] vir: $S y$ is so in die twintig" (bl. 128).

5. ... aansoek doen vir

GW, RD, HAT, NW, WAT, KG: om

SARA: "Aansoek doen om word aangevoel as formeel, maar dit is meestal ' $n$ formele handeling en daarom moet om voorkeur geniet. Aansoek doen [vir] 'n betrekking kom baie voor. Omdat vir sy 
terrein so uitbrei, is dit moontlik nie net Engelse invloed nie" (bl. 3-4). Kyk ook die opmerking in die KW hier onder.

KW: $\quad$ "Let ... daarop dat jy aansoeke om 'n betrekking vra, nie vir nie ... tog kan 'n mens nie loskom van die vraag of jy ... nie bloot met 'n tipiese Afrikaanse vorm te make het nie" (bl. 17). [Opmerking: Van der Merwe en Ponelis (bl. 148) merk oor die voorsetsel op: "Keer op keer word gevind dat die gangbare voorsetsel in Afrikaans heeltemal afwyk van dié in ouer en selfs moderne Nederlands ... Vir Afrikaans, en veral vir die voorsetsel, stel ek my al hoe meer op die standpunt dat ons die Afrikaanse taalgevoel (wat berus op ' $n$ bepaalde taalpatroon) in eerste instansie in aanmerking moet neem en eers in tweede instansie moet kyk wat die ouer taaltoestande ons te leer het." - AFP.]

VW: aansoek doen om (vir) 'n betrekking. Taljaard en Smit se verduideliking van woorde in ronde hakies is soos volg: "Woorde en uitdrukkings tussen ronde hakies kan as alternatiewe vir die laaste woord voor die hakies gebruik word". Dit val op dat vir nie op dieselfde wyse as by en op in die geval van "aan (by, op) die grens" behandel word nie. Daar word by en op onafhanklik ingeskryf, aldus:

aan: aan (by, op) die grens

by: sien aan

op: sien aan

Miskien verdien vir in hierdie stadium in dié woordeboek nog nie volle standaardstatus nie.

6. ... 'n sê hê in 'n saak

GW, HAT: seggenskap hê

RD: $\quad$ 'n sê hê in 'n saak

NW: seggenskap hê. As sinoniem word egter aangedui: ('n) sê.

WAT: Die kaartkorpus bevat 18 opgawes van sê as s.nw. in hierdie verband.

SARA: "Sê as naamwoord staan onder verdenking ... 'Jy (het) hier geen [sê] (seggenskap) nie'. Hier moet sê liewer vermy word" (bl. 139-140).

KW: $\quad$ "Ek het geen sê daarin nie (Angl.) = ... seggenskap nie" (bl. 169).

KG: "seggenskap - Dit beteken 'beslissingsreg' en kan nie deur $s \hat{e}$ as selfstandige naamwoord vervang word nie. Sê kan wel 'n naamwoordsfunksie hê,' maar dan in 'n verband soos 'sy sê sê"' (bl. 151). 
7. ... dien geen doel nie

GW: geen nut hê nie, vir niks deug nie

RD: $\quad$ dien nêrens toe nie, geen nut hê nie

HAT: waartoe dien dit? Opmerking: "Vir die anglisisme [sic] dit dien geen nuttige doel nie kan gebruik word dit het geen nut nie, is nutteloos."

NW: dien nêrens toe nie, is van geen nut nie

WAT: dien nêrens toe nie

SARA: "Dit [dien geen doel] nie is 'n onnodige Anglisisme. Afrikaans: Dit help nie, het geen nut nie, is nutteloos" (bl. 37).

KG: "'Die doel dien' is 'n Anglisisme wat vermy moet word" (bl. 50).

8. $\quad$... op die grens

RD: $\quad$ aan die grens

WAT: aan, by, op die grens

SARA: "'n Huis staan aan die see, by die see of langs die see ... In Engels word hier on gebruik wat in foutiewe Afrikaans letterlik vertaal word as [op]" (bl. 120-121).

VW: Dié woordeboek erken aan, by en op (kyk by item 5 hierbo).

KG: $\quad$ "Is dit aan die grens of op die grens? Tensy dit letterlik en presies op die grenslyn is, moet aan oorweeg word. Maar dit kan tot misverstand lei. As verneem word dat 'die soldaat aan die grens is', kan dit beteken dat die soldaat ò sy land help verdedig of in trane uitgebars het. 'n Uitweg is 'by die grens', wat presies sê wat 'aan die grens' sê, sonder ruimte vir misverstand" (bl. 72-73).

9. $\quad$... buite orde rëll

GW, RD: buite die orde verklaar

HAT: buite die orde reël

KW: $\quad$ "... Vermy ook die volgende Anglisismes: Die voorsitter het hom buite orde gereël (korrek: ... het hom buite die orde verklaar" (b]. 153).

KG: $\quad$ "As iets 'buite die orde verklaar word', beslis die voorsitter van 'n vergadering dat ' $n$ bepaalde punt ... Let op die verpligte 'die' in al die gevalle" (bl. 133). 
10. $\quad . .$. die rivier is in vloed

RD: $\quad$ riviere in vloed [Opmerking: Aan die Afrikaanse kant van dié woordeboek verskyn "riviere in vloed" en dit word vertaal met rivers in flood. Aan die Engelse kant word "the river is in flood" vertaal met "die rivier is vol of kom af of lê kant en wal" AFP.]

HAT: $\quad$ in rivier in vloed

NW: Betekenis 2 by vloed: "Oorstroming. Die rivier is in - " [lees vloed].

VW: in: die rivier is in vloed/ the river is in flood [Opmerking: Aangesien dit hier om die voorsetsel gaan, wonder 'n mens watter ander voorsetsels moontlik is. Dit lyk of die opstellers eerder die aanvaarbaarheid van die hele item wou aandui - AFP.]

11. ... 'n probleem oorkóm (met klem op -kom)

RD: $\quad$ sy moeilikhede oorkom

HAT: te bowe kom

NW: (ong.) baasraak, oorwin [Opmerking: Die NW se toeligting by "(ong.)" is: "Hierdie afkorting staan vir ongewoon. Daarmee word nie bedoel dat die woord 'n vakterm is nie, maar dat dit nie algemeen bekend of gebruiklik is nie" - AFP.]

WAT: Die kaartkorpus van die WAT het die volgende opgawes: gevare, siektes, probleme (5), beperktheid, moeilikheid (5), terugslag, agterstand, struikelblok (2), tekort, droefheid, leemtes oorkom.

KW: "Gewoonlik word aangevoer dat hierdie werkwoord net in die volgende gebruike toelaatbaar is: Jy moet oorkorn na ons toe; Dit het my al dikwels oorgekom; ... Hierteenoor word dan beweer dat oorkom in die betekenis 'oorwin; te bowe kom' onder invloed van Engels overcome staan. Dis egter onjuis. WNT gee 'n hele paar voorbeelde van hierdie gebruik aan. Dit is dus volkome korrek om jou moeilikhede te oorkom, iemand se besware te oorkom" (bl. 147).

KG: $\quad$ "Met die klem op die tweede lettergreep is dit sinoniem met 'te bowe kom"' (bl. 130).

12. ... te oordeel aan

GW, RD, HAT: volgens, na

NW: na

WAT: Die kaartkorpus van die WAT het die volgende opgawes: te oordeel na (16), aan (6), volgens (1). 
SARA: "Te oordeel na (sy voorkoms), is die vaste uitdrukking. Dáár kan niks anders as na gebruik word nie" (bl.119).

KW: Hoewel dit in die KW nie om die voorsetsel gaan nie, maar om die gebruik van oordeel naas beoordeel, is die voorbeeld: "Om te oordeel na wat jy sê ..." (bl. 146-147).

VW: $\quad$ te oordeel na

KG: $\quad$ "Die uitdrukking is 'te oordeel na' (nie 'aan' nie)" (bl. 130).

13. ... doen by H.aan

GW: die Kaap aandoen

RD: 'n hawe aandoen

HAT: die skip het Kaapstad aangedoen

NW: die skip doen twee hawens aan

WAT: $\quad$ "OPM. By' $n$ hawe ... aandoen is 'n foutiewe gebruik; die juiste vorm is sonder voorsetsel."

SARA: "Ons skip het Kaapstad aangedoen, sonder 'by'. Maar: Ek moet ... by my suster AANGAAN, met by" (bl. 1).

KW: $\quad$ Onderweg na Indië het die skepe gewoonlik Kaapstad ... aangedoen ... Ons sal dit wel as 'n Anglisisme beskou waar ons 'n voorsetsel daarby haal: Op pad Kaapstad toe het ek by Bloemfontein aangedoen" (bl. 2).

JW: Hiemstra (bl. 11) beskou dit as 'n kontaminasievorm van aangaan by en aandoen, en ook as Anglisisties.

VW: by: by iem. [lees: iemand] aandoen

by'n plek aandoen

KG: $\quad$ "'n Skip doen 'n hawe aan (sonder voorsetsel). Andersins: 'n skip gaan by 'n hawe aan" (bl. 11).

14. 'n belofte maak

GW, RD, WAT: 'n belofte doen, aflê

NW: aflê

SARA: "Iemand 'n belofte doen, klink plegtig, maar word beskou as die enigste regte vorm" (bl. 20).

15. ... vonnisse gelyktydig uitdien

GW, RD: Die Engelse bywoord "simultaneously" word vertaal met tegelykertyd. In Afrikaans behoort dit dus te wees: "Die vonnisse sal tegelykertyd uitgedien word."

KG: "gelyktydig - dit beteken 'wat tot dieselfde tydvak behoort' of 'wat op dieselfde tydstip gebeur', bv. 'gelyktydige (d.w.s. tydgenootlike/kontemporêre) skrywers' of 'die treine kom gelyktydig 
aan'. In laasgenoemde geval kan dit ook tegelykertyd, tegelyk of gelyk wees" (bl. 67).

16. melkskommel

GW: bruismelk, roomysmelk, skuimmelk

RD: $\quad$ bruismelk, roomysmelk

HAT, NW: bruismelk

WAT: bruismelk [maar het "Vgl. roomysmelk"]. In die kaartkorpus van die WAT is daar egter soveel opgawes met melkskommel dat dit kwalik weggelaat sou kon word.

\section{Die vraelys}

Daar is reeds vroeër in dié studie aangedui dat die sestien leksikale items aan 102 respondente voorgelê is en dat elke item beoordeel moes word op grond van sy gebruiklikheid $(\mathrm{G})$ of ongebruiklikheid $(O G)$, aanvaarbaarheid $(A)$ of onaanvaarbaarheid (OA) vir die respondent. "Gebruiklikheid" is soos volg verduidelik: "Met 'gebruiklik' word bedoel dat u die besondere stukkie taal redelik dikwels hoor - al is dit nie noodwendig deel van u eie taalgebruik nie."

Daar moet op gelet word dat geen druk op die respondente geplaas is om elke item volledig te beoordeel nie. Dit was opvallend dat persone hulle dikwels nie oor die gebruiklikheid en/of aanvaarbaarheid al dan nie van 'n spesifieke item wou uitlaat nie. As gevolg hiervan klop die getalle dus nie altyd nie, byvoorbeeld: In Tabel 1, item 4 het 21 uit die 23 respondente die item as "gebruiklik" beoordeel, maar 0 as "ongebruiklik", waar 'n mens eintlik sou verwag dat twee persone (die verskil tussen 21 en 23) dit as sodanig sou aangedui het. Op dieselfde wyse het 13 respondente dié item as "aanvaarbaar" beskou, maar slegs 5 (in plaas van die verwagte 10 ) het aangedui dat dit "onaanvaarbaar" was.

Hierdie verskynsel is in die bepaling van die persentasies verreken: die syfers het in elk geval so goed gekorreleer dat dit nie die gevolgtrekkings raak nie.

\section{Groep A}

Groep $A$ het bestaan uit 23 persone - onder meer twee lede van die Taalkommissie, ' $n$ redakteur en ' $n$ senior joernalis van ' $n$ Johannesburgse Afrikaanse middagkoerant, ' $n$ voormalige hoof van publikasies by die WNNR met dekadelange ervaring van redigering, 'n medesamesteller van 'n voorsetselwoordeboek, 'n mederedakteur van die Woordeboek van die Afrikaanse Taal, 'n ervare aanbieder van televisienuus, ' $n$ hoof van 'n Afrikaanse radiodiens en twee van 
sy omroepers, en vier dames in 'n Johannesburgse voorstad wat elkeen oor 'n B.A.-graad met Afrikaans as hoofvak beskik.

Tabel 1: Gebruiklikheid van 16 leksikale items

Groep A: 23 respondente - maksimum response: 368

(Afkortings: $G=$ gebruiklik $A=$ aanvaarbaar $O G=$ ongebruiklik

$\mathrm{OA}=$ onaanvaarbaar)

\section{Vraag}

1. Inflasie het gekom om te bly

2. 'n Klag/aanklag teen iemand lê

3. Tom P. sal die rekord breek

4. Die tellings is in die twintigs

5. Doen aansoek vir die pos

6. Sy het ' $n$ sê in die saak

7. Dit dien geen doel nie

8. Soldate op die grens

9. Buite orde reël

10. Die rivier is in vloed

11. Probleme oorkóm ("te bowe kom")

12. Te oordeel aan

13. Hy doen by Heilbron aan

14. 'n Belofte maak

15. Vonnisse gelyktydig uitdien

16. Melkskommel (bruismelk)

$\begin{array}{rrrr}\mathbf{G} & \mathbf{A} & \text { OG } & \text { OA } \\ 20 & 14 & 3 & 9 \\ 21 & 17 & 2 & 6 \\ 20 & 10 & 3 & 13 \\ 21 & 13 & 0 & 5 \\ 21 & 18 & 0 & 4 \\ 21 & 19 & 0 & 1 \\ 22 & 17 & 0 & 3 \\ 21 & 19 & 0 & 1 \\ 20 & 20 & 3 & 3 \\ 21 & 18 & 0 & 1 \\ 20 & 19 & 1 & 1 \\ 20 & 14 & 1 & 5 \\ 21 & 17 & 2 & 6 \\ 21 & 21 & 0 & 0 \\ 23 & 20 & 0 & 3 \\ 23 & 23 & 0 & 0 \\ & & & \\ 336 & 279 & 15 & 61\end{array}$

\section{TOTAAL}

\section{Bespreking van Tabel 1}

Dit val op dat dié groep nie die maksimum getal response (368) gelewer het nie. $95,3 \%$ (351) het oor die gebruiklikheid van die sestien items gehandel, waarvan $95,7 \%$ (336) bevestigend was. Hierteenoor het $92,4 \%$ oor die aanvaarbaarheid gegaan, met $82 \%$ wat bevestigend was.

Die item wat deur die meeste respondente van Groep A as onaanvaarbaar beskou is, is nr. 3: "Tom P. sal die rekord breek".

Al die respondente het item 16 (melkskommel) aanvaarbaar gevind. word:

Die response as persentasies van die maksimum kan soos volg opgesom
G: $\quad 91,3 \%$ (wissel van 86,9 tot 100 )
A: $\quad 75,8 \%$ (wissel van 43,5 tot 100 )
OA: $\quad 16,6 \%$ (hoogste is item $3-56,3$ ) 


\section{Groep B}

Groep B het bestaan uit 18 nuusskrywers by SAUK-televisie.

Tabel 2: Gebruiklikheid van 16 leksikale items

Groep B: 18 respondente - maksimum response: 288

(Afkortings: $G=$ gebruiklik $A=$ aanvaarbaar $O G=$ ongebruiklik

$\mathrm{OA}=$ onaanvaarbaar)

\section{Vraag}

1. Inflasie het gekom om te bly

2. 'n Klag/aanklag teen iemand lê

3. Tom P. sal die rekord breek

4. Die tellings is in die twintigs

5. Doen aansoek vir die pos

6. Sy het ' $n$ sê in die saak

7. Dit dien geen doel nie

8. Soldate op die grens

9. Buite orde reël

10. Die rivier is in vloed

11. Probleme oorkóm ("te bowe kom")

12. Te oordeel aan .

13. Hy doen by Heilbron aan

14. 'n Belofte maak

15. Vonnisse gelyktydig uitdien

16. Melkskommel (bruismelk)

$\begin{array}{rrrr}\mathbf{G} & \mathbf{A} & \text { OG } & \text { OA } \\ 13 & 8 & 5 & 10 \\ 15 & 10 & 3 & 8 \\ 15 & 7 & 3 & 11 \\ 13 & 11 & 5 & 7 \\ 16 & 13 & 2 & 5 \\ 17 & 14 & 1 & 4 \\ 17 & 14 & 1 & 4 \\ 16 & 17 & 2 & 1 \\ 16 & 14 & 2 & 4 \\ 17 & 14 & 1 & 4 \\ 17 & 13 & 1 & 5 \\ 17 & 13 & 1 & 5 \\ 14 & 7 & 4 & 11 \\ 17 & 17 & 1 & 1 \\ 17 & 13 & 1 & 5 \\ 17 & 15 & 1 & 3 \\ & & & \\ 254 & 200 & 34 & \mathbf{8 8}\end{array}$

TOTAAL

$254 \quad 200$

34
$-\quad 88$

\section{Bespreking van Tabel 2}

Groep B het die maksimum getal response (288) gelewer - 'n moontlike aanduiding dat ' $n$ nuusskrywer ' $n$ besluit MOET neem, of gewoon ' $n$ baie besliste mening oor taalsake nahou. Dit word dan ook daarin weerspieël dat hierdie groep verreweg die hoogste gemiddelde syfer $(30,6 \%)$ vir die onaanvaarbaarheid van die items opgelewer het. Dit was veral ten opsigte van items 1, 2, 3 en 13.

Hierteenoor het 17 van die 18 respondente items 8 ("soldate op die grens") en 14 ("'n belofte maak") aanvaarbaar gevind. word:

Die response as persentasies van die maksimum kan soos volg opgesom

G: $\quad 88,2 \%$ (wissel van 72,2 tot 94,4 )

A: $\quad 69,4 \%$ (wissel van 38,9 tot 94,4 )

OA: $\quad 30,6 \%$ (hoogste is item $3,13-61,1$ ) 


\section{Groep $C$}

Groep $C$ het bestaan uit twee groepe studente aan die Universiteit van Stellenbosch en enkele van die dosente van wie twee lede van die Taalkommissie is of was. Honneursstudente in Afrikaans en senior studente in die vertaalkunde het die vraelys voltooi.

\section{Tabel 3: Gebruiklikheid van 16 leksikale items \\ Groep C: 23 respondente - maksimum response: 368 \\ (Afkortings: $G=$ gebruiklik $A=$ aanvaarbaar $O G=$ ongebruiklik

$$
\mathrm{OA}=\text { onaanvaarbaar) }
$$

Vraag

1. Inflasie het gekom om te bly

2. 'n Klag/aanklag teen iemand $l \hat{e}$

3. Tom P. sal die rekord breek

4. Die tellings is in die twintigs

5. Doen aansoek vir die pos

6. Sy het 'n $n$ sê in die saak.

7. Dit dien geen doel nie

8. Soldate op die grens

9. Buite orde reël

10. Die rivier is in vloed

11. Probleme oorkóm ("te bowe kom")

12. Te oordeel aan

13. Hy doen by Heilbron aan

14. 'n Belofte maak

15. Vonnisse gelyktydig uitdien

16. Melkskommel (bruismelk)

TOTAAL

$\begin{array}{rrrr}\text { G } & \text { A } & \text { OG } & \text { OA } \\ 19 & 15 & 1 & 4 \\ 21 & 16 & 0 & 2 \\ 22 & 18 & 0 & 14 \\ 20 & 14 & 1 & 7 \\ 23 & 20 & 0 & 2 \\ 21 & 19 & 0 & 3 \\ 22 & 22 & 0 & 0 \\ 21 & 20 & 0 & 2 \\ 19 & 18 & 4 & 5 \\ 22 & 21 & 0 & 1 \\ 20 & 15 & 2 & 4 \\ 22 & 19 & 0 & 3 \\ 21 & 17 & 2 & 6 \\ 22 & 22 & 0 & 0 \\ 17 & 16 & 5 & 6 \\ 22 & 22 & 0 & 0\end{array}$

$334 \quad 294 \quad 15$

\section{Besprekīng van Tabel 3}

Die lede van dié groep het ook nie die maksimum getal response gelewer nie. Daar was 349 oor die gebruiklikheid van die items waarvan $334(95,7 \%)$ bevestigend was. Oor die aanvaarbaarheid was daar 343 response waarvan $294(85,7 \%)$ bevestigend was. 
Die groep het veral van die ander daarin verskil dat hulle items 4, 9, 13 en 15 meer onaanvaarbaar as item 3 beskou het. Hierteenoor het 22 uit die 23 respondente items 7,14 en 16 as aanvaarbaar aangedui. word:

Die response as persentasies van die maksimum kan soos volg opgesom

G: $\quad 90,8 \%$ (wissel van 73,9 tot 100 )

A: $\quad 79,9 \%$ (wissel van 60,9 tot 95,7 )

OA: $\quad 13,3 \%$ (hoogste is item $4-30,4$ )

\section{Groep D}

Groep $D$ het bestaan uit 15 omroepers van Radio Suid-Afrika (met uitsondering van die persone wat in groep $A$ was).

Tabel 4: Gebruiklikheid van 16 leksikale items

Groep D: 15 respondente - maksimum response: 240

(Afkortings: $\mathrm{G}=$ gebruiklik $\mathrm{A}=$ aanvaarbaar $\mathrm{OG}=$ ongebruiklik $\mathrm{OA}=$ onaanvaarbaar)

\section{Vraag}

1. Inflasie het gekom om te bly

2. 'n Klag/aanklag teen iemand lê

3. Tom P. sal die rekord breek

4. Die tellings is in die twintigs

5. Doen aansoek vir die pos

6. Sy het ' $n$ sê in die saak

7. Dit dien geen doel nie

8. Soldate op die grens

9. Buite orde reël

10. Die rivier is in vloed

11. Probleme oorkóm ("te bowe kom")

12. Te oordeel aan

13. Hy doen by Heilbron aan

14. 'n Belofte maak

15. Vonnisse gelyktydig uitdien

16. Melkskommel (bruismelk)

$\begin{array}{rrrr}\mathbf{G} & \mathbf{A} & \text { OG } & \text { OA } \\ 15 & 11 & 0 & 4 \\ 14 & 14 & 1 & 1 \\ 14 & 7 & 1 & 7 \\ 12 & 9 & 3 & 6 \\ 15 & 14 & 0 & 1 \\ 14 & 11 & 1 & 4 \\ 15 & 15 & 0 & 0 \\ 15 & 13 & 0 & 2 \\ 14 & 13 & 1 & 2 \\ 14 & 14 & 1 & 1 \\ 12 & 9 & 3 & 6 \\ 12 & 11 & 3 & 4 \\ 9 & 7 & 6 & 8 \\ 15 & 14 & 0 & 1 \\ 15 & 15 & 0 & 0 \\ 13 & 13 & 2 & 2\end{array}$

$218 \quad 190 \quad 22$ 
Bespreking van Tabel 4

Op een na (by item 3 ten opsigte van aanvaarbaarheid) is die maksimum getal response deur dié groep gelewer. Weer eens is items 3 en 13 as die onaanvaarbaarste beskou.

Al die respondente het items 7 en 15 as aanvaarbaar beskou.

Die response as persentasies van die maksimum kan soos volg opgesom word:

G: $\quad 90,8 \%$ (wissel van 60,0 tot 100 )

A: $\quad 79,2 \%$ (wissel van 46,7 tot 100 )

OA: $\quad 20,4 \%$ (hoogste is item $13-53,3$ )

\section{Groep E}

Groep $E$ het bestaan uit 23 nuusskrywers by SAUK-radio.

Tabel 5: Gebruiklikheid van 16 leksikale items

Groep D: 23 respondente - maksimum response: 368

(Afkortings: $G=$ gebruiklik $A=$ aanvaarbaar $O G=$ ongebruiklik $\mathrm{OA}=$ onaanvaarbaar)

\section{Vraag}

1. Inflasie het gekom om te bly

2. in Klag/aanklag teen iemand $l \hat{e}$

3. Tom P. sal die rekord breek

4. . Die tellings is in die twintigs

5. Doen aansoek vir die pos

6. Sy het ' $n$ sê in die saak

7. Dit dien geen doel nie

8. Soldate op die grens

9. Buite orde reël

10. Die rivier is in vloed

11. Probleme oorkóm ("te bowe kom")

12. Te oordeel aan

13. Hy doen by Heilbron aan

14. 'n Belofte maak

15. Vonnisse gelyktydig uitdien

16. Melkskommel (bruișmelk)
G

$23 \quad 20$

$23 \quad 20$

$19 \quad 11$

$16 \quad 14$

$20 \quad 13$

$23 \quad 21$

$19 \quad 18$

$23 \quad 18$

$18 \quad 15$

$20 \quad 19$

$12 \quad 15$

$22 \quad 22$

$18 \quad 15$

$22 \quad 21$

$23 \quad 22$

$23 \quad 22$

$324 \quad 286$
OG OA

$0 \quad 3$

03

$4 \quad 12$

$6 \quad 8$

27

$0 \quad 2$

12

$0 \quad 5$

47

12

118

11

58

12

$0 \quad 1$

0 


\section{Bespreking van Tabel 5}

Dié groep het ook nie die maksimum getal response (368) gelewer nie. Van die $97,8 \%$ van die maksimum ten opsigte van gebruiklikheid was $90 \%$ bevestigend. Van die $97,3 \%$ ten opsigte van aanvaarbaarheid was $79,9 \%$ bevestigend.

Item 3 is verreweg as die onaan vaarbaarste beskou, terwyl 22 van die 23 respondente van mening was dat items 12, 15 en 16 aanvaarbaar is. word:

Die response as persentasies van die maksimum kan soos volg opgesom

G: $\quad 88,0 \%$ (wissel van 52,2 tot 100 )

A: $\quad 77,7 \%$ (wissel van 47,8 tot 95,7 )

OA: $\quad 19,6 \%$ (hoogste is item $3-52,2$ )

Tabel 6: Gebruiklikheid van 16 leksikale items

Groep D: 102 respondente - maksimum response: 1632

(Afkortings: $G=$ gebruiklik $A=$ aanvaarbaar $O G=$ ongebruiklik $\mathrm{OA}=$ onaanvaarbaar)

\section{Vraag}

1. Inflasie het gekom om te bly

2. 'n Klag/aanklag teen iemand lê

3. Tom P. sal die rekord breek

4. Die tellings is in die twintigs

5. Doen aansoek vir die pos

6. Sy het 'n sê in die saak

7. Dit dien geen doel nie

8. Soldate op die grens

9. Buite orde reël

10. Die rivier is in vloed

11. Probleme oorkóm ("te bowe kom")

12. Te oordeel aan

13. Hy doen by Heilbron aan

14. 'n Belofte maak

15. Vonnisse gelyktydig uitdien

16. Melkskommel (bruismelk)

TOTAAL

$\begin{array}{rrrr}\text { G } & \text { A } & \text { OG } & \text { OA } \\ 90 & 68 & 9 & 30 \\ 94 & 77 & 6 & 20 \\ 90 & 53 & 11 & 47 \\ 82 & 61 & 15 & 33 \\ 95 & 78 & 4 & 19 \\ 96 & 84 & 2 & 14 \\ 95 & 86 & 2 & 9 \\ 96 & 87 & 2 & 11 \\ 87 & 80 & 14 & 21 \\ 94 & 86 & 3 & 9 \\ 81 & 71 & 18 & 24 \\ 93 & 79 & 6 & 18 \\ 83 & 63 & 19 & 39 \\ 97 & 95 & 2 & 4 \\ 95 & 86 & 6 & 15 \\ 98 & 95 & 3 & 6\end{array}$

$\begin{array}{llll}1466 & 1249 & 122 & 319\end{array}$ 
Samevatting van groepe $A$ tot $E$

Ten opsigte van gebruiklikheid is $97,3 \%$ (1588) van die maksimum getal response gelewer waarvan 92,3\% (1466) aangetoon het dat die 16 items oor die algemeen as gebruiklik ervaar word.

Ten opsigte van aanvaarbaarheid is $96,1 \%$ (1568) van die maksimum getal response ontvang waarvan $79,7 \%$ (1249) aangetoon het dat die 16 items oor die algemeen vir die respondente aanvaarbaar is.

Die behandeling van die leksikale items in die woordeboeke en taalhandleidings (hierna WTh) word vervolgens opsommend teenoor die gegewens in die vraelys gestel:

1. ... gekom om te bly

Die WTh bevat nie dié item nie; slegs die Engelse weergawe verskyn in die GW en RD. Dit is interessant dat $88,2 \%$ (90) van die respondente dit as gebruiklik beskou het - hoewel dit nie in woordeboeke voorkom nie. Sowat $30 \%$ (30) van die respondente het dit onaanvaarbaar gevind.

2. ...'n klaglaanklag lê

Met die uitsondering van die KW keur die WTh dit af: eersgenoemde beskou dit as "gevestig" - maar onder Engelse invloed. Die WAT bevat een sitaat met lê wat sy voorskrif ten gunste van indien weerspreek.

Vraelys: $92,2 \%$ (94) van die respondente vind dit gebruiklik; $75,5 \%$ (77) vind dit aanvaarbaar.

3. ... 'n rekord breek

Die RD en SARA beskou dié item as Standaardafrikaans - dié twee bronne word gesteun deur die resultate van die vraelys: $88,2 \%(90)$ van die respondente ervaar dit as gebruiklik. In teenstelling hiermee heers die gesag van die WTh nog steeds oor die taalgebruiker: $46,1 \%$ (47) van die respondente vind dit onaanvaarbaar.

Die verskynsel dat $10,8 \%$ (11) van die respondente dit as "ongebruiklik" aangedui het, moet opgeweeg word teenoor die feit dat dit tog in die WTh behandel word asof dit gebruiklik is - anders sou dit waarskynlik deur dié vraagbake geïgnoreer word.

4. ... in die twintigs

Die WTh keur dit uitsonderingloos as Anglisisme af. 80,4\% (82) van die respondente beskou dit as gebruiklik en $59,8 \%$ (61) aanvaar dit as standaardgebruik. 
5. ... aansoek doen vir

Die KW, en SARA laat die moontlikheid oop dat hierdie vir in wese Afrikaans is. Die VW beskou dit as Afrikaans naas om. 93,1\% (95) van die respondente ervaar dit as gebruiklik en vir $76,5 \%(78)$ is dit aanvaarbaar.

6. ... 'n sêhê in 'n saak

Die WTh keur dit hoofsaaklik af ten gunste van seggenskap hê (die RD is die uitsondering). Dié item is egter goed verteenwoordig in die kaartkorpus van die WAT. Wat die vraelys betref: $94,1 \%$ (96) van die respondente ervaar dit as gebruiklik; $82,4 \%(84)$ is tevrede dat dit aanvaarbaar is.

7. ... dien geen doel nie

Die WTh keur dit deur die bank af as Anglisisme. Vir 93,1\% (95) van die respondente is dit gebruiklik; vir $84,3 \%$ (86) is dit ook aanvaarbaar.

8. ... op die grens

Van die WTh het die WAT en VW op naas aan en by. 94,1\% (96) van die respondente ervaar dit as gebruiklik; $85,3 \%$ (87) beskou dit as aanvaarbaar.

9. ... buite orde reël

Die HAT is die enigste van die WTh wat buite die orde reël het. Dit is interessant dat dié woordeboek die "verpligte" die aandui: dit is nie deur enige van die respondente geopper nie: hulle ervaar duidelik die vorm soos dit as item 9 hierbo verskyn. $85,3 \%(87)$ het dit as gebruiklik aangedui en $78,4 \%(80)$ as aanvaarbaar.

Die feit dat $13,7 \%$ (14) dit as ongebruiklik beskou, kan moontlik daaraan toegeskryf word dat die item redelik min buite vergaderings gebruik word en dat ' $n$ aantal respondente dit dus nie dikwels hoor nie.

10. ... die rivier is in vloed

In die WTh verskyn dit in die RD (aan die Afrikaanse kant), HAT, NW en VW. Die taalhandleidings bevat nie inskrywings hieroor nie. Die RD vertaal dit egter van die Engelse kant af met "die rivier is vol of kom af of lê kant en wal".

Die meeste respondente ervaar dit ook as gebruiklik en beskou dit as aanvaarbaar. 
11. ... 'n probleem oorkóm

Hierdie item is ingesluit om die respondente se gevoel vir vermeende Engelse invloed te bepaal. Die WTh keur dit oorweldigend goed - die enigste sweempie van teenspraak is die NW wat dit as "ongewoon" etiketteer (waarmee bedoel word dat dit "nie algemeen bekend of gebruiklik" is nie).

Die response lewer veelseggende antwoorde op. Die 79,4\% (81) van die respondente wat dit in teenstelling met die NW as "gebruiklik" bestempel, verteenwoordig die laagste gebruiklikheidsyfer onder die 16 items. 23,5\% (24) respondente het dit as onaanvaarbaar beoordeel. Die vermeende invloed van Engels (die werkwoord "overcome"?) is waarskynlik die rede hiervoor.

Nog ' $n$ interessante verskynsel is die verband wat daar bestaan tussen sommige OA- en OG-response. Dit geld veral items 3, 4, 9, 11 en 13. Die rede daarvoor is nie duidelik nie - miskien is die respondent bewus van die teorie dat gebruik die maatstaf vir die insluiting van 'n leksikale item in die woordeboek (en dus vir aanvaarbaarheid) is. As hy die item dus nie as gebruiklik ervaar nie, is dit ook nie aanvaarbaar nie. (Die ander interessante moontlikheid is dat die respondent die item onaanvaarbaar vind, en dus besluit dat dit ongebruiklik behoort te wees.)

12. ... te oordeel aan

Behalwe enkele opgawes van te cordeel aan in die WAT se kaartkorpus, is die WTh eenparig in hulle afkeuring van dié item. $91,2 \%$ (93) van die respondente vind dit gebruiklik en $77,5 \%$ (79) aanvaarbaar.

13. ... doen by H. aan

Benewens die VW keur alle WTh's dit af, hoofsaaklik omdat dit as 'n Anglisisme beskou word. Die respondente gee baie duidelik te kenne dat hierdie item nie naastenby so aanvaarbaar is as die meeste ander nie: hoewel $81,4 \%$ (83) van hulle dit as gebruiklik ervaar, beskou $38,2 \%$ (39) dit as onaanvaarbaar. Miskien is dit ook veelseggend dat hierdie item die enigste onder die 16 proefitems is wat deur al 102 respondente beoordeel is, ten opsigte van gebruiklikheid sowel as aan vaarbaarheid.

14. ' $n$ belofte maak

Die WTh is eenparig dat aflê, doen die enigste korrekte vorms is. Die proefgroepe beskou hierdie item egter as volstrek gebruiklik en aanvaarbaar: 95,1\% (97) dui eersgenoemde en $93,1 \%$ (95) laasgenoemde aan. Slegs drie persone wou nie ' $n$ mening uitspreek nie. 
15. ... vonnisse gelyktydig uitdien

Die WTh is ook hier eenparig dat tegelykertyd gebruik moet word. Die respondente verskil daarvan: $93,1 \%$ (95) ervaar gelyktydig as gebruiklik en $84,3 \%$ (86) beskou dit as aanvaarbaar.

16. melkskommel

Hierdie woord verskyn nêrens in die WTh nie. 96,1\% (98) van die respondente meen dit is gebruiklik; $93,1 \%$ (95) vind dit aanvaarbaar. Daar is egter genoeg opgawes in die kaartkorpus van die WAT wat opname sal verseker.

\section{Die geldigheid van die response}

Voordat enige gevolgtrekking uit die studie aangebied word, moet die geldigheid van die vraelys kortliks bespreek word.

Wissing (1989:125-130), in 'n ondersoek na die aanvaarbaarheid van vraelyste in die taalkunde, stel die vraag so (bl. 126): "Watter argumente sou mens kon aanvoer dat die eienskappe van een groep studente (byvoorbeeld ' $n$ klas studente in Afrikaans-Nederlands) verteenwoordigend is van die eienskappe van die sprekers van SA?"

Sy vertrekpunt is.' $n$ aanname wat ook vroeër in hierdie studie gestel is: "Daar kan met redelike sekerheid aanvaar word dat byna-gegradueerde Afrikaanssprekende studente van Afrikaans grotendeels sprekers is van SA [lees: Standaardafrikaans]" (bl. 126).

Verder kom Wissing tot die gevolgtrekking dat die response van groepe studente aan verskillende Suid-Afrikaanse universiteite dermate ooreenstem dat "die proefpersone van enige universiteit in so 'n ondersoek gebruik sal kan word. ' $n$ Voorbehoud is dat die groep nie te klein moet wees nie" (bl. 129). Hy meld dan 'n arbitrêre syfer van 50 .

Verder meen hy (bl. 127) dat "dit eintlik nie gaan oor hoe naby aan mekaar die groepe se response ... lê nie (alhoewel dit op sigself ook betekenisvol kan wees) maar slegs of al die onderskeie groepe soortgelyk reageer".

Die response van die vyf groepe in die onderhawige studie lê so naby aan mekaar dat daar met groot stelligheid aanvaar kan word dat die response van groepe $A$ en $C$ verteenwoordigend is van die vyf groepe gesamentlik, ook wat die ander sowat 140 items soos huidiglik, verhaal op e.d.m. betref wat in die eerste vraelys vervat is.

Die response word dus as geldig aanvaar. 


\section{E. Gevolgtrekkings}

1. Die opname van leksikale items in Afrikaanse verklarende en vertalende woordeboeke berus in talle gevalle nie op gebruik soos wat in die leksikografieteorie te kenne gegee word nie. As dit so was, sou die items in die vraelys in dié woordeboeke verskyn het (item 11 verskyn reeds daar).

2. Waar sekere items wel op grond van gebruik opgeneem is, word dit deur middel van 'n etiket as 'n Anglisisme gemerk, waardeur die gebruik daarvan in Standaardafrikaans beperk word. Die gesag van die woordeboek is so sterk dat selfs vermeende Anglisismes (soos oorkom - item 11) by 'n groot persentasie opgevoede Standaardafrikaanssprekers onder verdenking staan. In hierdie opsig is dit ook insiggewend om daarop te let dat die item siende dat (wat volstrek deur die WTh as Anglisisme vir aangesien afgewys word) volgens. die kaartgegewens by die WAT reeds in die taalgebruik van Van Riebeeck en Trichardt te vinde is.

'n Voorskrif soos "vermy liewer as 'n ongewenste Anglisisme" neem in die geval van die proefitems beslis nie die gebruiklikheid van die item, of die aanvaarding daarvan deur die taalgemeenskap in ag nie.

3. Die hoë vlak van aanvaarbaarheid van die sestien proefitems dui ook daarop dat die opname van dié items geïnhibeer word op ander gronde as dié van gebruiklikheid.

4. Die feit dat die items in dié studie gemeet is aan hulle voorkoms in gesproke Afrikaans, soos ervaar en aanvaar deur die proefpersone, en dat die Afrikaanse leksikografie grotendeels afwysend daarteenoor staan (met die uitsondering van item 11) dui op 'n ernstige gebrek in die opname van verteenwoordigende items van die gesproke Standaardregister.

5. Aangesien juis woordeboeke (en in mindere mate taalhandleidings) deur taalpraktisyns (redigeerders, proeflesers e.d.m.) gebruik word om "foute" uit geskrewe of gepubliseerde tekste te weer, en hierbo aangedui is dat dié vraagbake juis talle gebruiklike en aanvaarbare leksikale items óf nie opneem nie, óf af wysend etiketteer, volg dit dat 'n bose kringloop tot stand kom: Hoofsaaklik geskrewe of gepubliseerde tekste word by die opstel van 'n woordeboek geëkserpeer - en dié tekste is op hulle beurt weer aan die hand van daardie woordeboek taalversorg.

6. Op grond van Wissing (1989) se bevindings kan ook gesê word dat nie slegs die 16 items van die onderhawige studie ter sprake is nie, maar ook die sowat 140 ander items van die voorlopige vraelys wat deur groepe $A$ en $C$ ingevul is. Die omvang van die gaping tussen woordeboek en gesproke Standaardafrikaans word daardeur aansienlik vergroot. 
Wanneer moet ' $n$ woordeboek sy opnamebeleid wysig, en miskien belangriker, waarom?

Die antwoord op die eerste deel van die vraag is: wanneer dit duidelik is dat sekere leksikale items gebruiklik is.

En waarom? Om te voorkom dat daar mettertyd 'n toestand as gevolg van diglossie ontstaan dat 'n puristiese, leksikografiese vorm van die Standaardtaal in verklarende en vertalende woordeboeke gaan verskyn wat deur weinig sprekers benut word ('n beskrywing wat Latyn ewe goed pas).

\section{Dankbetuiging}

Dank is verskuldig aan die persone wat vraelyste ingevul het, waaronder my kollegas by Radio Suid-Afrika en Televisie- en Radionuus; studente aan die Universiteit van Stellenbosch en sekere lede van die Taalkommissie en die Komitee vir Taaladvies. Die WAT het soos gewoonlik die kaartversameling tot my beskikking gestel - dankie daarvoor. Dank ook aan mnr. Johan Gloy van die SAUK se Taalburo vir hulp met onder meer die verwerking van die response.

\section{Bibliografie}

Combrink Johan en Johan Spies. 1986. SARA. Sakboek van regte Afrikans. Kaapstad: Tafelberg. De Villiers, M., J. Smuts, L.C. Eksteen en R.H. Gouws. 19877. Nasionale Woordeboek. Kaapstad: Tafelberg.

Du Plessis, E.T. 19812. Die kennis gids tot moderne Afrikaans. Kaapstad: Human en Rousseau.

Gouws, R.H. 1988. Die gebruik van etikette as leksikografiese hulpmiddel. SATT, Geleentheidsuitgave 6: 1-56.

Gouws, R.H. 1989. Leksikografie. Pretoria: Academica.

Hiemstra, L.W. 1980. Die juiste woord. Kaapstad: Tafelberg.

Kritzinger, M.S.B. en F.J. Labuschagne (Reds.). 19807. Verklarende Afrikaanse Woordeboek. Pretoria: Van Schaik.

Kritzinger, M.S.B., P.C. Schoonees, U.J. Cronjé en L.C. Eksteen (Reds.). 198613. Groot Woordeboek. Pretoria: Van Schaik.

Odendal, F.F. 1978. Die gesag van die woordeboek. Snyman, Henning (Red.). 1978: 65-77

Odendal, F.F. (Hoofred.). 19842. Verklarende Handwoordeboek van die Afrikaanse Taal. Johannesburg: Perskor.

Reader's Digest. 19883. Afrikaans-Engelse Woordeboek. Kaapstad: Reader's Digest.

Snyman, Henning (Red.). 1978. Uit vier windstreke. Kaapstad: Nasou.

Taljaard, P.J. en W.K. Smit. 19872. Voorsetselwoor déboek. Pretoria: De Jager-HAUM.

Van der Merwe, H.J.J.M. en F.A. Ponelis. $1982^{6}$. Die korrekte woord. Pretoria: Van Schaik.

Wissing, D.P. 1989. Steekproewe: 'n Kan of 'n moe't vir die taalkunde. SATT 7(3): 125-130.

Zgusta, L. 1971. Manual of Lexicography. Den Haag: Mouton. 